SHORT COMMUNICATION

\title{
Polymerization of 1,3-Dienes Containing Functional Groups 6: Unexpected Collapse of Monomer Structure in the Anionic Polymerization of 2-Ethoxymethyl-1,3-butadiene
}

\author{
By Katsuhiko TAKENAKA, ${ }^{*}$ Yusuke AKAGAWA, Hiroki TAKESHITA, \\ Masamitsu MIYA, and Tomoo SHIOMI
}

KEY WORDS: 2-Ethoxymethyl-1,3-butadiene / Anionic Polymerization / $\mathrm{S}_{\mathrm{N}} 2^{\prime}$ Type Reaction /

It is well known that the anionic polymerization of non-functional 1,3dienes such as 1,3-butadiene and isoprene is one of the best methods to prepare polydienes of well-characterized chain structure. ${ }^{1-3}$ This method can also be applicable for the polymerization of some dienyl monomers containing functional groups. Polymer of high cis-1,4-structure was obtained by the anionic polymerization of 2-(N,N-dialkylaminodimethylsilyl)-1,3-butadienes. ${ }^{4}$ Stadler and his coworkers have reported the anionic polymerization of various $N, N$-dialkylaminomethyl-1,3-butadienes. ${ }^{5}$ Polydienes having various microstructures were obtained depending on the steric bulkiness of the $N$-alkyl substituents. These reports indicate that dialkylamino function can survive under highly basic anionic polymerization condition. In addition, aminomethyl group attached to the butadienyl skeleton does not interfere the polymerization.

Among the various kinds of functional groups, alkyl ether is one of the most stable ones against wide range of reaction conditions. Since it does not react with propagating species, ethereal compounds such as tetrahydrofurane (THF) are often used as a solvent for anionic polymerization. In this paper we would like to report the anionic polymerization behavior of 2-ethoxymethyl-1,3-butadiene (1) having ethereal group.

\section{EXPERIMENTAL}

1 was synthesized from isoprene according to Scheme 1. Synthesis of 2bromomethyl-1,3-butadiene was descried elsewhere. ${ }^{6} \mathrm{In}$ a $100 \mathrm{~mL}$ roundbottomed flask, $4.50 \mathrm{~g}$ of $\mathrm{NaH}$ (purity $=60 \%$ ) was weighed. It was rinsed three times with hexane to remove mineral oil. Then $10 \mathrm{~mL}$ of dry THF was charged and $5.18 \mathrm{~g}$ of absolute ethanol was added dropwise to form sodium ethoxide solution. Cooling the solution at $0{ }^{\circ} \mathrm{C}, 11.81 \mathrm{~g}$ of 2-bromomethyl1,3-butadiene in $20 \mathrm{~mL}$ of dry THF was added dropwise for $30 \mathrm{~min}$ and stirred overnight at $40^{\circ} \mathrm{C}$. After usual workup, $5.64 \mathrm{~g}$ of 1 was isolated by distillation under reduce pressure. bp $50-54{ }^{\circ} \mathrm{C} / 40 \mathrm{mmHg}$. Yield $63 \%$. ${ }^{1} \mathrm{H}$ NMR: $\delta=6.35\left(\mathrm{dd}, 1 \mathrm{H}, \mathrm{J}=11,17 \mathrm{~Hz}, \mathrm{CH}_{2}=\mathrm{CH}-\right), \delta=5.29(\mathrm{~d}, 1 \mathrm{H}$, $\left.\mathrm{J}=17 \mathrm{~Hz}, \mathrm{CH}_{2}=\mathrm{CH}-\right), \delta=5.07\left(\mathrm{~d}, 1 \mathrm{H}, \mathrm{J}=11 \mathrm{~Hz}, \mathrm{CH}_{2}=\mathrm{CH}-\right), \delta=5.23$ (s, $1 \mathrm{H}, \mathrm{CH}_{2}=\mathrm{C}$ ), $\delta=5.14$ (s, $1 \mathrm{H}, \mathrm{CH}_{2}=\mathrm{C}$ ), $\delta=4.07$ (s, 2H, C-CH $-\mathrm{O}-$ ), $\delta=3.49\left(\mathrm{q}, 2 \mathrm{H}, \mathrm{J}=7 \mathrm{~Hz}, \mathrm{CH}_{3}-\mathrm{CH}_{2}-\right), \delta=1.20\left(\mathrm{t}, 3 \mathrm{H}, \mathrm{J}=7 \mathrm{~Hz}, \mathrm{CH}_{3}-\right)$, ${ }^{13} \mathrm{C}-\mathrm{NMR}: \quad \delta=142.7 \quad\left(\mathrm{CH}_{2}=\mathrm{C}-\right), \quad \delta=136.6 \quad\left(\mathrm{CH}_{2}=\mathrm{CH}-\right), \quad \delta=116.7$ $\left(\mathrm{CH}_{2}=\mathrm{CH}-\right), \quad \delta=114.1 \quad\left(\mathrm{CH}_{2}=\mathrm{C}-\right), \quad \delta=70.2 \quad\left(\mathrm{C}-\mathrm{CH}_{2}-\mathrm{O}-\right), \quad \delta=65.7$ $\left(\mathrm{CH}_{3}-\mathrm{CH}_{2}-\mathrm{O}-\right), \delta=15.5\left(\mathrm{CH}_{3}\right)$.

1 was stirred over night with small amount of $\mathrm{LiAlH}_{4}$ and distilled under high vacuum condition. Finally it was diluted with THF or heptane and used for anionic polymerization using break-seal method.

${ }^{1} \mathrm{H}$ NMR spectrum was recorded with a JEOL JNM-AL-400 spectrometer in $\mathrm{CDCl}_{3}$. Size exclusion chromatography (SEC) chromatogram was obtained using a TOSOH HLC-8220 instrument. Matrix assisted laser desorption ionization time-of-flight mass spectroscopy (MALDI-ToF-MS) was performed using an Applied Biosystems Voyager DE-RP instrument

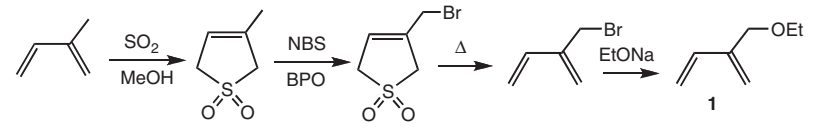

Scheme 1.

with linear and delayed-extraction mode. A small amount of sodium iodide was added to enhance the sample ionization, and 2,5-dihydroxybenzoic acid was used as the matrix.

\section{RESULTS AND DISCUSSION}

Upon addition of the THF solution of $\mathbf{1}$ to potassium naphthalenide (K-Naph), characteristic green color turned immediately to dark brown and gradually changed to deep red in $18 \mathrm{~h}$. That color disappeared instantaneously by the addition of ethanol. After polymerization, considerable amount of monomer was recovered from the polymerization mixture. In the case of the polymerization in heptane using $s e c-\mathrm{BuLi}$ as an initiator, no apparent coloration was observed throughout the reaction.

Table I summarizes the anionic polymerization of $\mathbf{1}$ with conventional anionic initiators. In either of the cases, no polymer was obtained regardless of the initiator and the monomer to initiator ratio. Since the monomer to initiator ratio was low enough, purity of the monomer should not be the reason for this non-polymerizable feature. Another possible explanation would be a proton abstraction from the allylic ethoxymethylene group. If so, such a side reaction could be detected by using polymeric macro initiators because the residual dead initiators can be recovered from the reaction mixture and analyzed in detail. Thus we chose here polystyryl anions as macroinitiators.

Table II summarizes the anionic polymerization of $\mathbf{1}$ with polystyryl anion as an initiator. All the polystyryl anions were prepared in THF at $-78^{\circ} \mathrm{C}$ using sec-BuLi, Li-Naph or K-Naph. Polymerization of $\mathbf{1}$ was carried out for $18-24 \mathrm{~h}$ at $-78^{\circ} \mathrm{C}$. In any cases, observed molecular weights measured by SEC were smaller than the calculated ones, though molecular weight distribution was narrow.

Figure 1 shows ${ }^{1} \mathrm{H}$ NMR spectrum of polymers prepared with secBuLi-initiated polystyryllithium as an initiator. Although signals attributable to methyl group of $s e c-\mathrm{BuLi}$, methylene, methine, and aromatic ring of polystyrene were clearly observed around $0.8,1.4,1.9$, and $6.5-7.2 \mathrm{ppm}$, respectively, no characteristic signals correspond to poly 1 segment was observed. This indicates that polymer thus obtained is not a block copolymer expected but is close to polystyrene. The only difference between ordinary polystyrene and the polymer obtained here is that the latter polymer shows some olefinic protons signals around 4.5-6.2 ppm. The signal pattern of these olefinic protons was close to those of isoprene. 
Table I. Anionic polymerization of $\mathbf{1}$ with conventional anionic initiators

\begin{tabular}{|c|c|c|c|c|c|c|c|}
\hline \multicolumn{2}{|c|}{ Initiator } & \multirow{2}{*}{$\begin{array}{c}1 \\
\mathrm{mmol}\end{array}$} & \multirow{2}{*}[1]{$/[\mathrm{l}]^{\mathrm{a}}$} & \multirow{2}{*}{ solvent } & \multirow{2}{*}{$\begin{array}{c}\text { Temp. } \\
{ }^{\circ} \mathrm{C}\end{array}$} & \multirow{2}{*}{$\begin{array}{c}\text { Time } \\
\mathrm{h}\end{array}$} & \multirow{2}{*}{$\begin{array}{c}\text { Yield } \\
\%\end{array}$} \\
\hline Type & $\mathrm{mmol}$ & & & & & & \\
\hline K-Naph & 0.260 & 5.12 & 20 & THF & -78 & 18 & 0 \\
\hline K-Naph & 0.177 & 5.99 & 33 & THF & -78 & 18 & 0 \\
\hline sec-BuLi & 0.610 & 7.65 & 13 & heptane & 0 & 24 & 0 \\
\hline sec-BuLi & 0.156 & 5.26 & 34 & heptane & 40 & 24 & 0 \\
\hline
\end{tabular}

${ }^{a}$ monomer to initiator ratio

Table II. Anionic polymerization of 1 in $\mathrm{THF}$ at $-78^{\circ} \mathrm{C}$ with polystyryl anion as an initiator

\begin{tabular}{lcccccc}
\hline \multicolumn{2}{c}{ Initiator } & $\begin{array}{c}\text { St } \\
\mathrm{mmol}\end{array}$ & $\begin{array}{c}\mathbf{1} \\
\mathrm{mmol}\end{array}$ & $\begin{array}{c}M_{\mathrm{n} \text { calc }} \\
\mathrm{kg} / \mathrm{mol}\end{array}$ & $\begin{array}{c}M_{\mathrm{n}} \mathrm{SEC} \\
\mathrm{kg} / \mathrm{mol}\end{array}$ & $M_{\mathrm{w}} / M_{\mathrm{n}}$ \\
\cline { 1 - 5 } Type & $\mathrm{mmol}$ & & & & \\
\hline sec-BuLi & 0.230 & 9.40 & 4.83 & 6.66 & 4.79 & 1.12 \\
Li-Naph & 0.250 & 11.3 & 4.83 & 13.7 & 9.12 & 1.10 \\
K-Naph & 0.550 & 9.59 & 6.72 & 6.36 & 4.78 & 1.14 \\
\hline
\end{tabular}

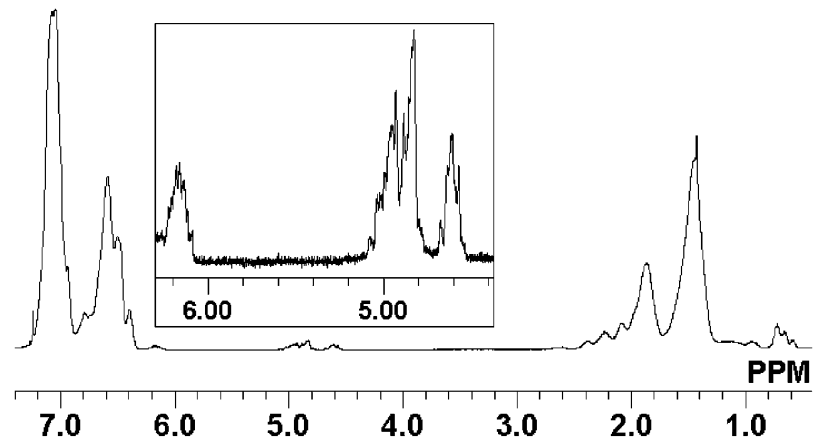

Figure 1. ${ }^{1} \mathrm{H}$ NMR spectrum of polymers prepared with sec-BuLi-initiated polystyryl anion as an initiator.

Further information about this polymer structure was provided by MALDIToF-MS analysis.

Figure 2 shows MALDI-ToF-MS of the same polymer. A series of signals appear in $104 \mathrm{Da}$ intervals, and no signals having $112 \mathrm{Da}$ interval that corresponds to the molar mass of $\mathbf{1}$ was observed. This strongly indicates that the resulting polymer is not a block copolymer. Since the anionic polymerization of styrene was initiated by sec-BuLi, polymer segment should have butyl group at the $\alpha$-chain end. If $\omega$-end block has molar mass of $\mathrm{Z}$, the molar mass of polystyrene $i$-mer should be

$$
\mathrm{M}_{i}=57.11+104.15 \times i+\mathrm{Z}+22.99
$$

where 57.11, 104.15, and 22.99 are molar mass of sec-butyl group, styrene, and sodium, respectively. When the following points, 1) polymer contains isoprene like olefinic protons 2) polymer does not contain ethoxy proton, are considered, one of the likely reaction occurred here is the formation of isoprenyl unit at the $\omega$ chain end accompanying the elimination of ethoxy group as illustrated in Scheme 2. If so, the $\omega$-end blocker is isoprenyl group whose molar mass $\mathrm{Z}=67.11$. Thus calculated molar mass of $\mathrm{Na}^{+}$adduct of 40-mer comes to 4313.21, which is close enough to the observed value 4312.42. This mechanism, a kind of $\mathrm{S}_{\mathrm{N}} 2^{\prime}$ type reaction, ${ }^{7}$ should be called "back side collapse." Similar reaction was reported by Hirao et al. in the anionic polymerization of styrene derivatives containing benzyl silyl ether

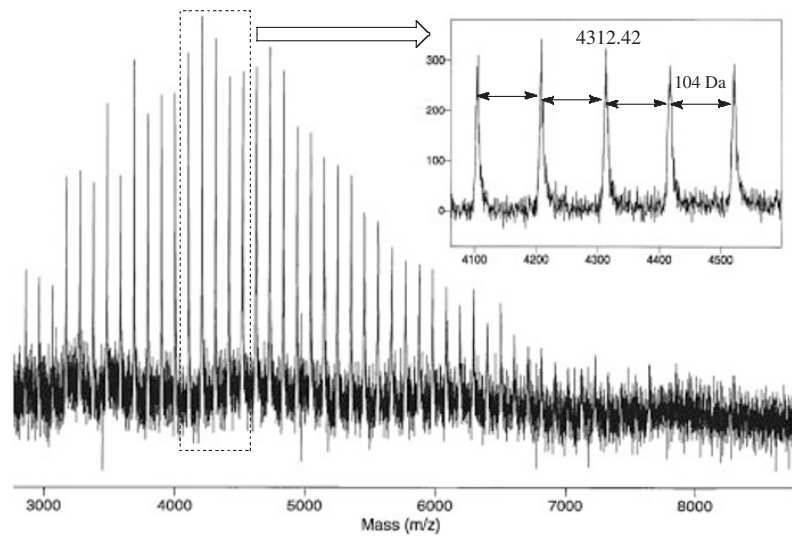

Figure 2. MALDI-ToF-MS of the polymer prepared with sec-BuLi initiated polystyryl anion as an initiator.

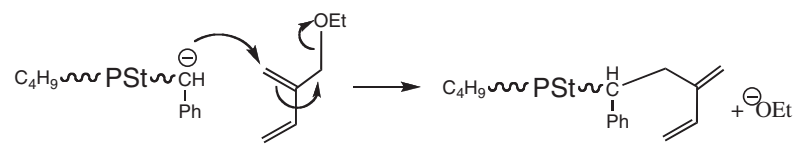

Scheme 2.

function. ${ }^{8}$ Comparing the polymerization behavior of alkoxymethyl-1,3butadiene with that of previously reported dialkylaminomethyl-1,3-butadiene, ${ }^{5}$ the less basic nature of ethoxide anion compared with dialkylamide anion caused the difference.

Thus it comes to be clear that 2-ethoxymethyl-1,3-butadiene can not be polymerized by anionic mechanism because of unexpected collapse of monomer structure under polymerization condition. Effect of other ethereal alkyl group and spacer length between oxygen atom and butadienyl skeleton on the polymerization behavior is now under investigation.

Received: September 11, 2008

Accepted: October 14, 2008

Published: December 5, 2008

\section{REFERENCES}

1. H. L. Hshieh and R. P. Quirk, "Anionic Polymerization Principles and Practical Applications," Marcel Dekker, New York, 1996.

2. A. Z. Niu, J. Stellbrink, J. Allgaier, L. Willner, D. Richter, B. W. Koenig, M. Gondorf, S. Willbold, L. J. Fetters, and R. P. May, "Proceedings of the 2003 International Symposium on Ionic Polymerization and Related Processes," Macromolecular Symposia Volume 215, J. W. Mays and R. F. Storey, Ed., Wiley Interscience, 2004, p 1.

3. M. Morton, "Anionic Polymerization: Principles and Practice," Academic press, New York, 1983.

4. A. Hirao, Y. Hiraishi, S. Nakahama, and K. Takenaka, Macromolecules, 31, 281 (1998).

5. C. Petzhold, R. Morschhauser, H. Kolshorn, and R. Stadler, Macromolecules, 27, 3707 (1994)

6. V. V. Sheares, L. Wu, Y. Li, and T. Emmick, J. Polym. Sci., Part A: Polym. Chem., 38, 4070 (2000).

7. J. March, "Advanced Organic Chemistry: Reactions, Mechanisms, and Structure," 4th ed., Wiley-Interscience, New York, 1992, p 328.

8. A. Hirao, K. Kitamura, K. Takenaka, and S. Nakahama, Macromolecules, 26, 4995 (1993). 